Published in final edited form as:

J Neurovirol. 2012 June ; 18(3): 191-199. doi:10.1007/s13365-012-0097-y.

\title{
Clinical Features and Virological Correlates of Neurocognitive Impairment among HIV-Infected Individuals in Nigeria
}

\author{
Walter Royal III ${ }^{1}$, Mariana Cherner ${ }^{4}$, Jean Carr ${ }^{2}$, Abdulrazaq G. Habib ${ }^{2}$, Abimbola \\ Akomolafe $^{3}$, Alashl'e. Abimiku ${ }^{2}$, Manhattan Chaurat ${ }^{2}$, John Farley ${ }^{2}$, Akinwande Oluyemisi ${ }^{4}$, \\ Ibrahim Mamadu ${ }^{4}$, Joyce Johnson ${ }^{2}$, Ronald Ellis ${ }^{5}$, Allen McCutchen ${ }^{5}$, Igor Grant ${ }^{5}$, and \\ William A. Blattner ${ }^{2}$ \\ ${ }^{1}$ Department of Neurology, University of Maryland School of Medicine \\ ${ }^{2}$ Institute of Human Virology, University of Maryland School of Medicine \\ ${ }^{3}$ Department of Medicine, Morehouse School of Medicine, The University of San Diego School of \\ Medicine \\ ${ }^{4}$ Institute of Human Virology-Nigeria, The University of San Diego School of Medicine \\ ${ }^{5}$ Department of Psychiatry, HIV Neurobehavioral Center, The University of San Diego School of \\ Medicine
}

Abstract

In Nigeria the incidence and prevalence of HIV related neurocognitive impairment (NCI) are unknown and there currently exists little information related to the viral correlates rates of NCI. Therefore studies were performed to examine the potential utility of applying an established neuropsychological (NP) screening battery and detailed NP testing to detect NCI and correlations with functional impairment and the presence of specific viral signatures among infected subjects. $60 \mathrm{HIV}-1$ seropositive antiretroviral-naive individuals and 56 seronegative control subjects were administered the International HIV Dementia Scale (IHDS) and assessed for functional impairment using the Karnofsky Performance Status Scale. 15 HIV infected patients and 11 controls were also administered a detailed NP battery. Blood samples from 8 infected subjects, 3 with evidence of NCI, were obtained for molecular analysis of HIV-1 strain. Unadjusted scores on the IHDS showed that, using a recommended total score cutoff of $10,28.8 \%$ of the HIV-1 seropositive and $16.0 \%$ of seropositive individuals scored abnormally. The mean Karnofsky score for the HIV seropositive and seronegative groups were, respectively, $90.7+12.2$ and $98.8+3.8$ $(\mathrm{p}<0.0001)$. Results from testing using the full NP battery showed that overall the HIV seropositive group performed worse than the seronegative group, with effect sizes spanning from small ( 0.25 on the Trail Making Test A) to large ( 0.82 on Action Fluency), with an average effect size across the battery of 0.45 , which approaches that which has been recorded in other international settings. Finally, sequencing of partial pol amplicons from viral isolates revealed that 2 of 3 patients with NCI were infected with subtype G virus and 1 with the circulating recombinant form (CRF) 02_AG; all 4 individuals without NCI were infected with CRF_02AG. These studies demonstrate the utility of conducting these studies for establishing the burden of $\mathrm{NCI}$ in the population of individuals with HIV-1 infection in Nigeria and for assessing the functional consequences and the virologic correlates of NCI.

\section{Introduction}

Current estimates indicate that there are approximately 33 million people with HIV infection worldwide and that two thirds of such individuals live in Sub-Saharan Africa. For Nigeria, the total number of people with HIV infection ranks second in the world (National Agency 
for the Control of Aids, 2010). Prior to the introduction of highly active antiretroviral therapies neurological complication were observed in up to $70 \%$ of individuals, with a significant number of the cases being associated with opportunistic processes (Berger et al., 1987; Levy et al., 1985; Snider et al., 1983). Among the most common and devastating complications is the occurrence of HIV dementia (Antinori et al., 2007). In Western and Sub-Saharan Africa, studies have demonstrated prevalence rates of HIV dementia that range from approximately 3\% to greater than 60\% (Belec et al., 1989; Hall et al., 2000; Howlett et al., 1989; Kanmogne et al., 2010; Njamnshi et al., 2009; Perriens et al., 1992; Robertson et al., 2005; Sacktor et al., 2006; Sebit, 1995; Wong et al., 2007). In Nigeria, antiretroviral drug therapies were relatively recently introduced and the use of these agents has been on the rise (Abimiku, 2009; Lum et al., 2007). In countries where antiretroviral medications are widely available a decline in the incidence of HIV dementia has been documented (Sacktor et al., 2001); however the prevalence has been found to remain elevated and to primarily impact individuals with earlier stage disease (Heaton et al., 2011; Sacktor et al., 2002).

There is currently a paucity of information related to the epidemiology of NCI in Nigeria as well as significant gaps in knowledge regarding potential associations between NCI risk and infection with specific HIV strains. Therefore, pilot studies were undertaken whereby patients and control subjects were screened for impairment using an instrument that has been shown to be sensitive for detecting cognitive abnormalities in HIV-infected individuals. This was followed by testing of a subgroup of this cohort with a more detailed neuropsychological battery and analyses of virus subtype in blood. These studies suggest that the prevalence of HIV-related neurological impairment in Nigeria may be similar to that previously reported in other international settings. Such impairment may be linked to HIV strains that account for a large percentage of the infections that occur among individuals in Nigeria.

\section{Results}

\section{Participant Demographic and Clinical Characteristics}

The age, gender, education, marital status and level of disability were compared for the HIV infected and seronegative individuals. The HIV infected groups were older and more likely to be female and married than the seronegative controls (table 1). There was no difference in the level of education with more than $35 \%$ of the subjects enrolled in each group achieving a post-high school level of education (table 1).

\section{Performance on the International HIV Dementia Scale}

HIV-infected and seronegative subjects were assessed for NCI using the IHDS tool. The groups were found to score similarly on the screen subtests. However, the HIV infected subject group had a lower mean total score than the seronegative group (table 2). Using a Karnofsky score of $<50$ as a gold standard, it was determined that the IHDS had a sensitivity of $100 \%$ and a specificity of $79 \%$ for detecting impairment at a total score cut-off of 9.0 and a sensitivity of $100 \%$ and a specificity of only $37 \%$ at a cut-off of 10.0 . With this information, the data were then examined to identify demographic and clinical factors that might be associated with poor performance on the IHDS, with this analysis performed using a score cut-off of 9.0. These studies showed that a statistically significant greater number of individuals with low CD4 cell counts and with higher WHO disease stage scores were below this cut-off (table 2). There was no association for a Karnofsky score >90 with scoring below a cut-off of 9.0 on the IHDS (data not shown). However a borderline association was noted for a Karnofsky score $<50$ (i.e., the individual required considerable assistance and frequent medical care) and an IHDS score $<9.0$ (table 2). 


\section{Performance of HIV Seropositive and Seronegative Participants on a Detailed Neuropsychological Battery}

A detailed NP battery was administered to 11 seronegative and 15 seropositive individuals. For the individuals in these two groups there was no difference in level of education, which is the variable that has the most influence on NP test performance. Overall, however, the HIV seropositive group performed worse than the seronegative group, with effect sizes on the individuals tests spanning from small (effect size 0.15 on the Trail Making Test A; $\mathrm{p}=$ non-significant) to large (effect size 0.82 on Action Fluency and 0.81 on the HVLT-R Delay, $\mathrm{p}$ value $=0.049$ and 0.044 , respectively) (table 3 ). The average effect size across the battery was 0.45 , which approaches the medium effect size that has been recorded in other international settings (figure 1).

\section{Molecular Analysis of HIV Isolates}

HIV isolates from 7 patients were analyzed for the presence of pol genetic sequence alterations that have been previously described for viral strains in Nigeria (Abimiku et al., 1994). All of the patients had been evaluated using the IHDS and with detailed NP test battery. Three of the seven patients had evidence of neurocognitive impairment and 4 had normal test results. Partial $\mathrm{pol}$ amplicons were successfully sequenced for all patients. Five of the seven were infected with CRF02_AG and two with subtype G strain virus. Among the three individuals with NCI two were infected with subtype G and one was CRF02_AG. All of the 4 without NCI were infected with CRF02_AG. No previously described HIV "neurological signatures" associated with CNS virus were observed in the env sequences analyzed from peripheral blood (data not shown). The results for the partial pol analysis are shown in a phylogenetic tree containing reference strains from the West African pandemic (figure 2).

\section{Discussion}

This study represents the first to examine among HIV infected individuals in Nigeria potential links between NCI, functional impairment and molecular virological evidence of infection with specific HIV strains. The neuropsychological screening instrument that was utilized, the IHDS, was shown to be sensitive for detecting impairment, initially in Uganda and subsequently in other populations, including those in Cameroon and India (Ganasen et al., 2008; Njamnshi et al., 2008; Riedel et al., 2006; Sacktor et al., 2005). In our cohort, mean total scores on the IHDS were slightly lower for the seropositive than for the seronegative group. In addition, at an IHDS total score cut-off of 9.0, seropositive subjects were found to be more impaired than seronegative subjects. Such impairment was associated with lower CD4 counts and more advanced HIV disease, the latter was reflected by the higher WHO disease stage for these individuals. Also, individuals who performed better on the screen were likely to have less functional impairment, as measured by Karnofsky Performance Status Scale scores, though this association was of borderline statistical significance. Karnofsky Scale scores reflect a combination of multiple functional parameters that are not directly related to what is assessed by the IHDS, however. Therefore, links between such scores and performance on this cognitive screen have to be interpreted with caution.

Studies using a more detailed neuropsychological battery that are also described in this report suggest an association between HIV infection in Nigeria and the presence of abnormalities in verbal fluency and verbal learning. These findings are, however, preliminary and need to be confirmed and expanded upon in larger cohorts and using culturally adapted tests. Studies of HIV-related neurocognitive impairment that have been previously performed in Nigeria have employed a culturally appropriate screening tool 
called the Community Screening Interview for Dementia (CSI 'D'), which was developed for studies of Alzheimer's disease (Odiase et al., 2006). In a cross-sectional study comparing treatment-naïve asymptomatically infected individuals to seronegative control subjects, the HIV infected group performed worse on the battery subtests and had lower total scores than control subjects. In a follow up study of performance on tests of simple reaction and binary choice reaction times in seropositive patients and seronegative control subjects matched for age, sex and level of education, the HIV infected patients were, again, more impaired (Odiase et al., 2006). At this time the prevalence of HIV related neurocognitive disorders in Nigeria is unknown. In Western countries during the early years of the decade it was estimated that HIV dementia occurred in between 10-15\% (Sacktor et al., 2002). With the introduction of effective antiretroviral therapy the incidence of HIV related neurocognitive impairment in the West initially decreased but has subsequently increased in association with a higher prevalence of impairment due to increased survival and with such individuals having milder impairment (Sacktor et al., 2001). Therefore, with the rapid increase in the use of antiretroviral therapies in countries such as Nigeria, it is important to track the impact of treatment on the prevalence of neurocognitive impairment in these settings as well.

The neuropathogenesis of HIV has been intensively studied in regions of the world where the predominant subtype of HIV-1 in circulation is subtype B and studies have been underway to examine the pathogenicity of subtype $\mathrm{C}$, which predominates in Southern Africa as well as in India (Weniger et al., 1994). In India studies suggest that the rate of dementia among individuals infected with clade $\mathrm{C}$ virus is lower than that which occurs with infection with clade B, whereas in South Africa high rates of dementia with clade C infection have been reported. In studies performed in Uganda there was an association demonstrated for cognitive impairment and severe immunosuppression with infection with subtype D virus (Sacktor et al., 2009). In Nigeria the molecular diversity of HIV has been examined in several studies and has been found to be complex. In regions to the west of Nigeria the most common genetic form of HIV is the circulating recombinant form CRF02_AG, which was formed from subtypes A and G (Abimiku et al., 1994; McCutchan et al., 1999). To the east, in the countries of west central Africa, particularly Cameroon which shares border with Nigeria, every genetic form of HIV that is known has been identified, including strains from groups $\mathrm{O}$ and $\mathrm{N}$. Neurotropic strains of HIV typically use the CCR5 chemokine receptor as a co-receptor to infect blood monocytes, which can transport the virus across the blood-brain barrier (Deng et al., 1996; Meltzer et al., 1990), and the chemokines and CCL5, MIP-1a/CCL3 and MIP-1 $\beta / C C L 4$ can block infection of these cells by HIV-1 (Alkhatib et al., 1996). Upon entry into the nervous system, virus can continue to replicate in these cells and, upon secretion, infect microglial cells, which also express CCR5 (Gartner et al., 1986; He et al., 1997; Shieh et al., 1998). The selective CCR5 binding is conferred by characteristic sequences that are located in the V3 loop region of the viral gene glycoprotein (Hwang et al., 1991). Also, CNS isolates can be found to have changes in the promoter sequences located in HIV long terminal repeat (LTR) that can be associated with altered binding of C/EBP family transcription factors (Burdo et al., 2004). Therefore, specific sequence changes in these regions may not only characterize virus that is compartmentalized in the nervous system also strains that may be specifically associated with a presence of cognitive impairment in the infected individual.

Following the establishment of infection, several factors can contribute to the development of neurocognitive impairment as a result of toxicity to neurons and glia, including the HIV proteins tat, gp120, and nef and cytokines and chemokines such as TNF- $a$, IL-1- $\beta$, MCP-1/ CCL2, other neurotoxic substances such as quinolinate and cellular toxicity induced by oxidative stress (Anderson et al., 2002; Heyes et al., 1991; Nath, 2002; Ranki et al., 1995; Wesselingh et al., 1993). Studies have shown that tat protein that is produced by clade C virus induced less toxicity against human fetal neurons and lower levels of expression of 
MCP-1/CCL2 by astrocytes in culture than that which is isolated from clade B virus, which correlates with the associated risk for individuals infected with these viruses developing HIV-related neurocognitive impairment. The possibility that CRF_AG strain virus can cause neurological disease is suggested by the findings for the small group of patients that are described in this report. However, further studies involving larger numbers of patients and data demonstrating macrophage tropism for clinical isolates from cognitively impaired individuals will be important to obtain.

Small scale studies in Africa of individuals infected with non-clade B virus have confirmed the effectiveness of antiretroviral drug therapy in reversing the symptoms of HIV-associated cognitive impairment in these populations (Sacktor et al., 2006). The introduction of HAART regimens has resulted in an approximately $50 \%$ decrease in the overall incidence of HIV dementia, although the prevalence of the disorder has unfortunately increased in association with prolonged survival of infected individuals (Dore et al., 1999; Sacktor et al., 2002). The overall efficacy of nucleoside reverse transcriptase inhibitors in penetrating the blood-brain barrier and in suppressing CSF viral replication when administered alone or in combination with other categories of antiretroviral drugs has been well documented (Foudraine et al., 1998; Foudraine et al., 2001). However, the ability of the antiretroviral drug to cross the blood-brain barrier can vary among different individuals and it is not clear that antiretroviral drug levels in CSF accurately reflect drug concentrations in brain or correlate with antiviral activity (Anthonypillai et al., 2006; Letendre et al., 2000). To address this issue an approach has been developed whereby the clinical efficacy of a drug regimen can be estimated based on the individual component drug chemical structure, antiviral potency and CSF penetration (Letendre et al., 2008; Tozzi et al., 2009). As regimens are developed for implementation in developing areas of the world such approaches will be useful in selecting drug combinations with the greatest efficacy against prevalent viral strains.

In summary, these studies of HIV related neurocognitive impairment in Nigeria confirm previous observations of such complications being detectable using screening instruments and more detailed testing approaches that are derived from tools used in other areas of the world. Also, just as previous applications of these instruments have been useful for determining risk for future negative consequences of HIV infection, performance on the testing can correlate with functional impairment. With the existence of a relatively limited diversity of viral strains in Nigeria there is the potential to identify strains that are particularly neurotropic and may respond best to specific antiretroviral drugs. Therefore, additional studies are critical for clarifying these remaining questions.

\section{Methods}

\section{Patients}

A total of 60 HIV seropositive subjects, all antiretroviral treatment naïve, and 56 seronegative individuals were sequentially recruited for these studies from counseling and testing clinics located at the National Hospital (NH) in Abuja, Nigeria, the University of Abuja Teaching Hospital (UATH) in Gwagwalada, Nigeria, and the Amino Kano Teaching Hospital (AKTH) in Kano, Nigeria. The clinics are operated under the University of Maryland AIDS Care and Treatment in Nigeria (ACTION) program, which is supported by the President's Emergency Plan for AIDS Relief (PEPFAR) fund. All individuals were $\geq 18$ years of age and had no history of active tuberculosis, syphilis or other infections. Individuals were excluded if they had a history of prior antiretroviral therapy, were nonEnglish speaking, had evidence of active CNS or systemic disease that would impair their ability to participate in the testing, a history of significant head trauma, focal neurological signs or other physical deficits that would impair performance, a history or alcohol abuse or 
use of other mind-altering substances, or a previous diagnosis of a learning disability or psychiatric disorder. Informed consent was obtained from the study participants independently or with the assistance of a family member. Volunteers also underwent phlebotomy with subsequent measurement of CD4 count and plasma viral RNA levels. All study procedures were approved by the University of Maryland Institutional Review Board, the Nigerian National Health Research Ethics Committee and by the Institution Review Boards of the NH, UATH and AKTH.

\section{Neuropsychological Testing}

Testing was performed on all study volunteers using the International HIV Dementia Scale, a brief neuropsychological screen that can be performed at the bedside in less than 20 minutes (Sacktor et al., 2005). In addition, a detailed neuropsychological battery that has been utilized in multiple international settings was administered to a subset of individuals to identify possible impairment within seven cognitive domains of interest. The domains tested and the specific tests utilized were the following: 1) Speed of Information Processing: WAIS-III Digit Symbol, WAIS-III Symbol Search, Color Trails Test 1, Trail Making Test A; 2) Attention/Working Memory: Paced Auditory Serial Addition Task (PASAT), WMSIII Spatial Span; 3) Abstraction/Executive Functioning: Wisconsin Card Sorting TestComputer Version, Color Trails Test 2, Stroop Color and Word Test, Halstead Category Test; 4) Learning and Delayed Recall: Hopkins Verbal Learning Test, Brief Visuospatial Memory Test; 5) Verbal Fluency: Letter (Word Sound) Fluency, Category Fluency; 6) Motor Speed and Dexterity: Grooved Pegboard Test; 7) Screening for Effort: Hiscock Digit Memory Test.

\section{Genetic Subtyping and Phylogenetic Analysis}

For characterization of the genetic subtype of HIV-1 in samples, proviral HIV-1 DNA was extracted from peripheral blood mononuclear cells (PBMCs) and amplified using a nested polymerase chain reaction (PCR) strategy. Subsequently, the amplified products were analyzed by nearly full genome sequencing using an ABI 3100 automated sequencer (Applied Biosystems, Foster City, CA) as previousy described (Eyzaguirre et al., 2007). For phylogenetic analysis, sequences were added to already existent multiple alignments containing reference sequences from the HIV-1 pandemic and hand-aligned using MacGDE, a sequence management software package for Apple Mac OSX (http://www.msu.edu/ lintone/macgde/). A sequence mask enabled insertions and deletions to be eliminated from phylogenetic analysis while remaining in the alignment. Phylogenetic analyses were done using neighbor-joining and maximum likelihood methods as implemented by Phylogeny Inference Package (PHYLIP) software Version 3.57c (J. Felsenstein, University of Washington)(Felsenstein, 1995). Intersubtype recombinations were determined by the use of SimPlot (Lole et al., 1999).

\section{References}

1. Abimiku AG. Building laboratory infrastructure to support scale-up of HIV/AIDS treatment, care, and prevention: in-country experience. Am. J Clin. Pathol. 2009; 131:875-886. [PubMed: 19461097]

2. Abimiku AG, Stern TL, Zwandor A, Markham PD, Calef C, Kyari S, Saxinger WC, Gallo RC, Robert-Guroff M, Reitz MS. Subgroup G HIV type 1 isolates from Nigeria. AIDS Res. Hum. Retroviruses. 1994; 10:1581-1583. [PubMed: 7888214]

3. Alkhatib G, Combadiere C, Broder CC, Feng Y, Kennedy PE, Murphy PM, Berger EA. CC CKR5: a RANTES, MIP-1alpha, MIP-1beta receptor as a fusion cofactor for macrophage-tropic HIV-1. Science. 1996; 272:1955-1958. [PubMed: 8658171] 
4. Anderson E, Zink W, Xiong H, Gendelman HE. HIV-1-associated dementia: a metabolic encephalopathy perpetrated by virus-infected and immune-competent mononuclear phagocytes. J. Acquir. Immune. Defic. Syndr. 2002; 31(Suppl 2):S43-S54. [PubMed: 12394782]

5. Anthonypillai C, Gibbs JE, Thomas SA. The distribution of the anti-HIV drug, tenofovir (PMPA), into the brain, CSF and choroid plexuses. Cerebrospinal. Fluid Res. 2006; 3:1. [PubMed: 16390539]

6. Antinori A, Arendt G, Becker JT, Brew BJ, Byrd DA, Cherner M, Clifford DB, Cinque P, Epstein LG, Goodkin K, Gisslen M, Grant I, Heaton RK, Joseph J, Marder K, Marra CM, McArthur JC, Nunn M, Price RW, Pulliam L, Robertson KR, Sacktor N, Valcour V, Wojna VE. Updated research nosology for HIV-associated neurocognitive disorders. Neurology. 2007; 69:1789-1799. [PubMed: 17914061]

7. Belec PL, Testa J, Vohito MD, Gresenguet G, Martin MI, Tabo A, Di Costanzo B, Georges AJ. [Neurologic and psychiatric manifestations of AIDS in Central African Republic]. Bull. Soc. Pathol. Exot. Filiales. 1989; 82:297-307. [PubMed: 2766440]

8. Berger JR, Moskowitz L, Fischl M, Kelley RE. Neurologic disease as the presenting manifestation of acquired immunodeficiency syndrome. South. Med J. 1987; 80:683-686. [PubMed: 3473692]

9. Burdo TH, Gartner S, Mauger D, Wigdahl B. Region-specific distribution of human immunodeficiency virus type 1 long terminal repeats containing specific configurations of CCAAT/ enhancer-binding protein site II in brains derived from demented and nondemented patients. J Neurovirol. 2004; 10(Suppl 1):7-14. [PubMed: 14982733]

10. Deng H, Liu R, Ellmeier W, Choe S, Unutmaz D, Burkhart M, di Marzio P, Marmon S, Sutton RE, Hill CM, Davis CB, Peiper SC, Schall TJ, Littman DR, Landau NR. Identification of a major coreceptor for primary isolates of HIV-1. Nature. 1996; 381:661-666. [PubMed: 8649511]

11. Dore GJ, Correll PK, Li Y, Kaldor JM, Cooper DA, Brew BJ. Changes to AIDS dementia complex in the era of highly active antiretroviral therapy. AIDS. 1999; 13:1249-1253. [PubMed: 10416530]

12. Eyzaguirre LM, Erasilova IB, Nadai Y, Saad MD, Kovtunenko NG, Gomatos PJ, Zeman VV, Botros BA, Sanchez JL, Birx DL, Earhart KC, Carr JK. Genetic characterization of HIV-1 strains circulating in Kazakhstan. J. Acquir. Immune. Defic. Syndr. 2007; 46:19-23. [PubMed: 17514018]

13. Felsenstein, J. Phylogeny Inference Package (PHYLIP). 1995.

14. Foudraine NA, Hoetelmans RM, Lange JM, de Wolf F, van Benthem BH, Maas JJ, Keet IP, Portegies P. Cerebrospinal-fluid HIV-1 RNA and drug concentrations after treatment with lamivudine plus zidovudine or stavudine [see comments]. Lancet. 1998; 351:1547-1551. [PubMed: 10326538]

15. Foudraine NA, Jurriaans S, Weverling GJ, Burger DM, Hoetelmans RM, Roos MT, Maas J, Miedema F, Reiss P, Portegies P, de Wolf F, Lange JM. Durable HIV-1 suppression with indinavir after failing lamivudine-containing double nucleoside therapy: a randomized controlled trial. Antivir. Ther. 2001; 6:55-62. [PubMed: 11417762]

16. Ganasen KA, Fincham D, Smit J, Seedat S, Stein D. Utility of the HIV Dementia Scale (HDS) in identifying HIV dementia in a South African sample. J Neurol. Sci. 2008; 269:62-64. [PubMed: 18237748]

17. Gartner S, Markovits P, Markovitz DM, Betts RF, Popovic M. Virus isolation from and identification of HTLV-III/LAV-producing cells in brain tissue from a patient with AIDS. JAMA. 1986; 256:2365-2371. [PubMed: 3490587]

18. Hall KS, Gao S, Emsley CL, Ogunniyi AO, Morgan O, Hendrie HC. Community screening interview for dementia (CSI 'D'); performance in five disparate study sites. Int. J. Geriatr. Psychiatry. 2000; 15:521-531. [PubMed: 10861918]

19. He J, Chen Y, Farzan M, Choe H, Ohagen A, Gartner S, Busciglio J, Yang X, Hofmann W, Newman W, Mackay CR, Sodroski J, Gabuzda D. CCR3 and CCR5 are co-receptors for HIV-1 infection of microglia. Nature. 1997; 385:645-649. [PubMed: 9024664]

20. Heaton RK, Franklin DR, Ellis RJ, McCutchan JA, Letendre SL, Leblanc S, Corkran SH, Duarte NA, Clifford DB, Woods SP, Collier AC, Marra CM, Morgello S, Mindt MR, Taylor MJ, Marcotte TD, Atkinson JH, Wolfson T, Gelman BB, McArthur JC, Simpson DM, Abramson I, Gamst A, Fennema-Notestine C, Jernigan TL, Wong J, Grant I. HIV-associated neurocognitive 
disorders before and during the era of combination antiretroviral therapy: differences in rates, nature, and predictors. J. Neurovirol. 2011; 17:3-16. [PubMed: 21174240]

21. Heyes MP, Brew BJ, Martin A, Price RW, Salazar AM, Sidtis JJ, Yergey JA, Mouradian MM, Sadler AE, Keilp J, Rubinow D, Markey SP. Quinolinic acid i cerebrospinal fluid and serum in HIV-1 infection: relationsyip to clinical and neurological status. Ann. Neurol. 1991; 29:202-209. [PubMed: 1826418]

22. Howlett WP, Nkya WM, Mmuni KA, Missalek WR. Neurological disorders in AIDS and HIV disease in the northern zone of Tanzania. AIDS. 1989; 3:289-296. [PubMed: 2504233]

23. Hwang SS, Boyle TJ, Lyerly HK, Cullen BR. Identification of the envelope V3 loop as the primary determinant of cell tropism in HIV-1. Science. 1991; 253:71-74. [PubMed: 1905842]

24. Kanmogne GD, Kuate CT, Cysique LA, Fonsah JY, Eta S, Doh R, Njamnshi DM, Nchindap E, Franklin DR Jr, Ellis RJ, McCutchan JA, Binam F, Mbanya D, Heaton RK, Njamnshi AK. HIVassociated neurocognitive disorders in sub-Saharan Africa: a pilot study in Cameroon. BMC. Neurol. 2010; 10:60. [PubMed: 20626870]

25. Letendre S, Marquie-Beck J, Capparelli E, Best B, Clifford D, Collier AC, Gelman BB, McArthur JC, McCutchan JA, Morgello S, Simpson D, Grant I, Ellis RJ. Validation of the CNS PenetrationEffectiveness rank for quantifying antiretroviral penetration into the central nervous system. Arch. Neurol. 2008; 65:65-70. [PubMed: 18195140]

26. Letendre SL, Capparelli EV, Ellis RJ, McCutchan JA. Indinavir population pharmacokinetics in plasma and cerebrospinal fluid. The HIV Neurobehavioral Research Center Group. Antimicrob. Agents Chemother. 2000; 44:2173-2175. [PubMed: 10898694]

27. Levy RM, Bredesen DE, Rosinblum ML. Neurological manifestations of the acquired immunodeficiency syndrome (AIDS): experience at UCSF and review of the literature. J Neurosurg. 1985; 62:475-495. [PubMed: 2983051]

28. Lole KS, Bollinger RC, Paranjape RS, Gadkari D, Kulkarni SS, Novak NG, Ingersoll R, Sheppard HW, Ray SC. Full-length human immunodeficiency virus type 1 genomes from subtype Cinfected seroconverters in India, with evidence of intersubtype recombination. J. Virol. 1999; 73:152-160. [PubMed: 9847317]

29. Lum H, Isichei C, Isichei-Wakili M, Redfield R. Expansion of HIV-1 screening and anti-retroviral treatment programs in a resource-poor setting: results from a faith-based organization in Jos, Plateau State, Nigeria. Afr Health Sci. 2007; 7:93-100. [PubMed: 17594286]

30. McCutchan FE, Carr JK, Bajani M, Sanders-Buell E, Harry TO, Stoeckli TC, Robbins KE, Gashau W, Nasidi A, Janssens W, Kalish ML. Subtype G and multiple forms of A/G intersubtype recombinant human immunodeficiency virus type 1 in Nigeria. Virology. 1999; 254:226-234. [PubMed: 9986789]

31. Meltzer MS, Skillman DR, Gomatos PJ, Kalter DC, Gendelman HE. Role of mononuclear phagocytes in the pathogenesis of human immunodeficiency virus infection. Annu. Rev. Immunol. 1990; 8:169-94. [PubMed: 2188662]

32. Nath A. Human immunodeficiency virus (HIV) proteins in neuropathogenesis of HIV dementia. J. Infect. Dis. 2002; 186(Suppl 2):S193-S198. [PubMed: 12424697]

33. National Agency for the Control of Aids. United Nations General Assembly Special Session (UNGASS) Country Progress Report: Nigeria. 2010.

34. Njamnshi AK, Bissek AC, Ongolo-Zogo P, Tabah EN, Lekoubou AZ, Yepnjio FN, Fonsah JY, Kuate CT, Angwafor SA, Dema F, Njamnshi DM, Kouanfack C, Djientcheu VP, Muna WF, Kanmogne GD. Risk factors for HIV-associated neurocognitive disorders (HAND) in sub-Saharan Africa: the case of Yaounde-Cameroon. J. Neurol. Sci. 2009; 285:149-153. [PubMed: 19631349]

35. Njamnshi AK, Djientcheu VP, Fonsah JY, Yepnjio FN, Njamnshi DM, Muna WE. The International HIV Dementia Scale is a useful screening tool for HIV-associated dementia/ cognitive impairment in HIV-infected adults in Yaounde-Cameroon. J Acquir. Immune. Defic. Syndr. 2008; 49:393-397. [PubMed: 19186351]

36. Odiase F, Ogunrin O, Ogunniyi A. Effect of progression of disease on cognitive performance in HIV/AIDS. J. Natl. Med. Assoc. 2006; 98:1260-1262. [PubMed: 16916122] 
37. Perriens JH, Mussa M, Luabeya MK, Kayembe K, Kapita B, Brown C, Piot P, Janssen R. Neurological complications of HIV-1-seropositive internal medicine inpatients in Kinshasa, Zaire. J. Acquir. Immune. Defic. Syndr. 1992; 5:333-340. [PubMed: 1312594]

38. Ranki A, Nyberg M, Ovod V, Haltia M, Elovaara I, Raininko R, Haapasalo H, Krohn K. Abundant expression of HIV Nef and Rev proteins in brain astrocytes in vivo is associated with dementia. AIDS. 1995; 9:1001-1008. [PubMed: 8527071]

39. Riedel D, Ghate M, Nene M, Paranjape R, Mehendale S, Bollinger R, Sacktor N, McArthur J, Nath A. Screening for human immunodeficiency virus (HIV) dementia in an HIV clade C-infected population in India. J. Neurovirol. 2006; 12:34-38. [PubMed: 16595372]

40. Robertson K, Kopnisky K, Mielke J, Appiah K, Hall C, Price R, Kumwenda J, Kanyama C, Amod F, Marra C, Taylor T, Lalloo U, Jelsma J, Holding P, Boivin M, Birbeck G, Nakasujja N, Sanne I, Parsons TD, Parente A, Tucker K. Assessment of neuroAIDS in Africa. J. Neurovirol. 2005; 11(Suppl 1):7-16. [PubMed: 15960235]

41. Sacktor N, Lyles RH, Skolasky R, Kleeberger C, Selnes OA, Miller EN, Becker JT, Cohen B, McArthur JC. HIV-associated neurologic disease incidence changes:: Multicenter AIDS Cohort Study, 1990-1998. Neurology. 2001; 56:257-260. [PubMed: 11160967]

42. Sacktor N, McDermott MP, Marder K, Schifitto G, Selnes OA, McArthur JC, Stern Y, Albert S, Palumbo D, Kieburtz K, De Marcaida JA, Cohen B, Epstein L. HIV-associated cognitive impairment before and after the advent of combination therapy. J. Neurovirol. 2002; 8:136-142. [PubMed: 11935465]

43. Sacktor N, Nakasujja N, Skolasky R, Robertson K, Wong M, Musisi S, Ronald A, Katabira E. Antiretroviral therapy improves cognitive impairment in HIV+ individuals in sub-Saharan Africa. Neurology. 2006; 67:311-314. [PubMed: 16864825]

44. Sacktor N, Nakasujja N, Skolasky RL, Rezapour M, Robertson K, Musisi S, Katabira E, Ronald A, Clifford DB, Laeyendecker O, Quinn TC. HIV subtype D is associated with dementia, compared with subtype A, in immunosuppressed individuals at risk of cognitive impairment in Kampala, Uganda. Clin Infect. Dis. 2009; 49:780-786. [PubMed: 19622045]

45. Sacktor NC, Wong M, Nakasujja N, Skolasky RL, Selnes OA, Musisi S, Robertson K, McArthur JC, Ronald A, Katabira E. The International HIV Dementia Scale: a new rapid screening test for HIV dementia. AIDS. 2005; 19:1367-1374. [PubMed: 16103767]

46. Sebit MB. Neuropsychiatric HIV-1 infection study: in Kenya and Zaire cross-sectional phase I and II. Cent. Afr. J. Med. 1995; 41:315-322. [PubMed: 8556777]

47. Shieh JT, Albright AV, Sharron M, Gartner S, Strizki J, Doms RW, Gonzalez-Scarano F. Chemokine receptor utilization by human immunodeficiency virus type 1 isolates that replicate in microglia. J Virol. 1998; 72:4243-4249. [PubMed: 9557714]

48. Snider WD, Simpson DM, Nielsen S, Gold JW, Metroka CE, Posner JB. Neurological complications of acquired immune deficiency syndrome: analysis of 50 patients. Ann. Neurol. 1983; 14:403-18. [PubMed: 6314874]

49. Tozzi V, Balestra P, Salvatori MF, Vlassi C, Liuzzi G, Giancola ML, Giulianelli M, Narciso P, Antinori A. Changes in cognition during antiretroviral therapy: comparison of 2 different ranking systems to measure antiretroviral drug efficacy on HIV-associated neurocognitive disorders. J Acquir. Immune. Defic. Syndr. 2009; 52:56-63. [PubMed: 19731418]

50. Weniger BG, Takebe Y, Ou CY, Yamazaki S. The molecular epidemiology of HIV in Asia. AIDS. 1994; 8(Suppl 2):S13-S28. [PubMed: 7857556]

51. Wesselingh SL, Power C, Glass JD, Tyor WR, McArthur JC, Farber JM, Griffin JW, Griffin DE. Intracerebral cytokine messenger RNA expression in acquired immunodeficiency syndrome dementia. Ann. Neurol. 1993; 33:576-582. [PubMed: 8498837]

52. Wong MH, Robertson K, Nakasujja N, Skolasky R, Musisi S, Katabira E, McArthur JC, Ronald A, Sacktor N. Frequency of and risk factors for HIV dementia in an HIV clinic in sub-Saharan Africa. Neurology. 2007; 68:350-355. [PubMed: 17261681] 


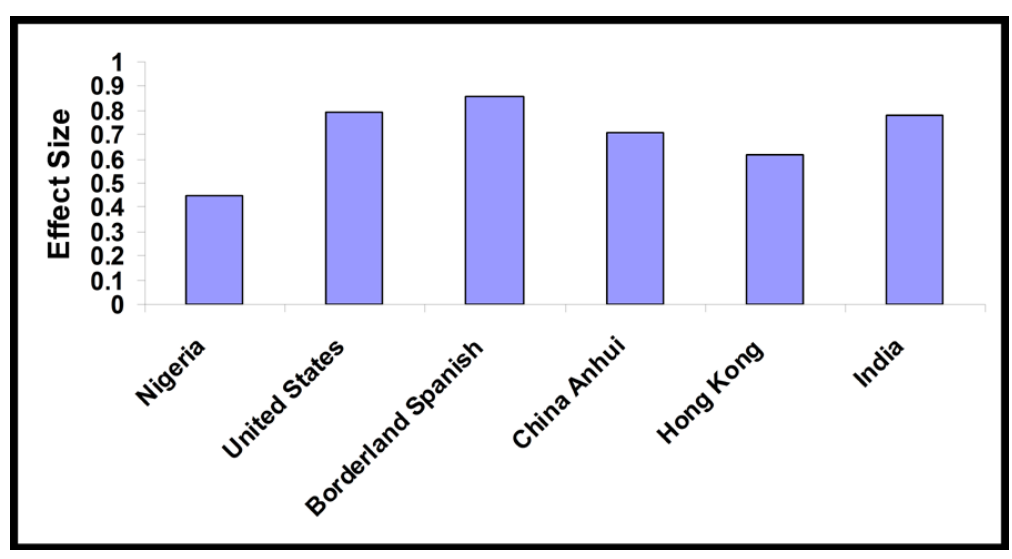

figure 1.

Comparison of the effect sizes determined for the individuals components of the detailed neuropsychological battery administered in Nigeria versus in the U.S. and in other international settings. 


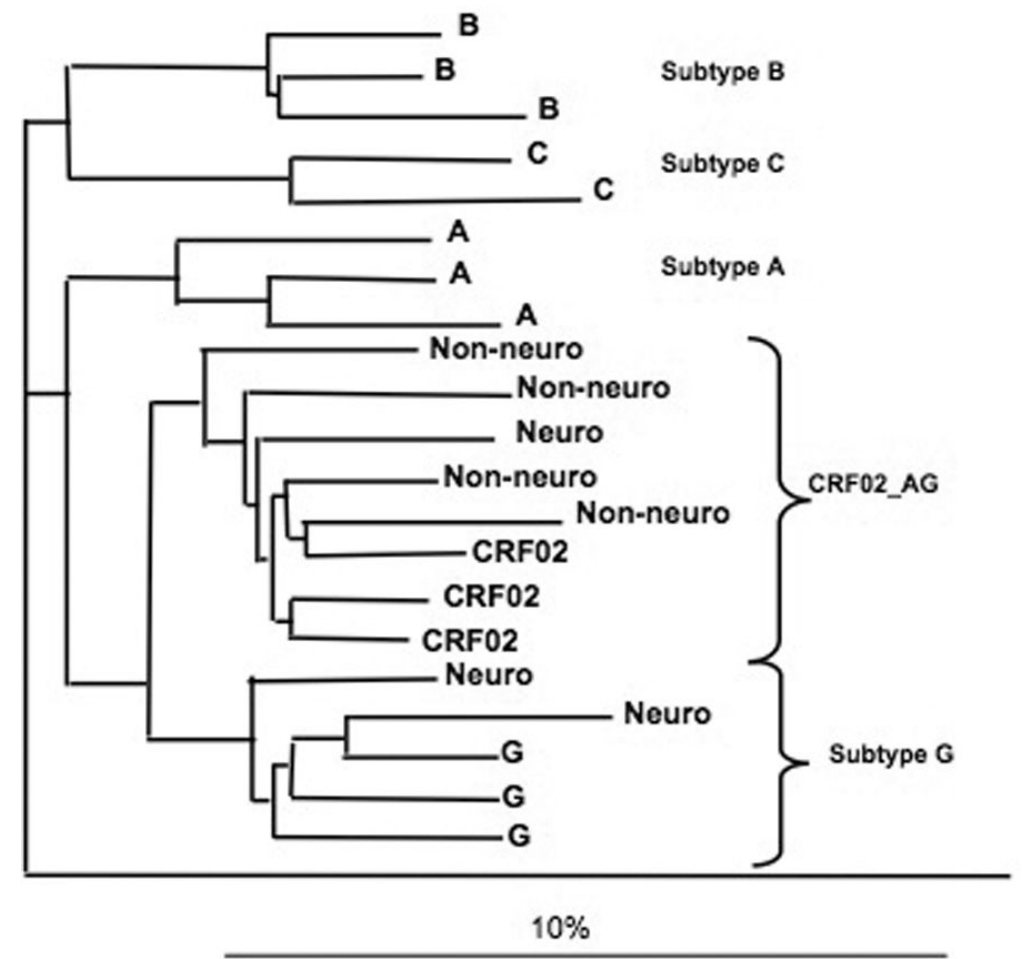

figure 2.

Results of molecular analysis of $p o l$ gene sequences from HIV isolates from 7 HIV seropositive subjects, 4 with NCI as determined by abnormal scores on the IHDS (Neuro) and 3 without NCI (Non-neuro). 
Table 1

Demographic Characteristics, Disability Status and IHDS Score for the HIV Seropositive and Seronegative Subjects

\begin{tabular}{|l|c|c|c|}
\hline Group & HIV+ & HIV- & P values \\
\hline Number of subjects & 60 & 56 & \\
\hline Mean Age (SD) & $34.0(7.4)$ & $29.4(8.3)$ & 0.002 \\
\hline Gender & & & \\
Females (\%) & $37(61.7)$ & $22(39.3)$ & 0.02 \\
\hline Education (\%) & & & \\
None/Primary & $12(26.1)$ & $5(10.6)$ & \\
Secondary & $15(32.6)$ & $15(31.9)$ & 0.12 \\
Tertiary & $19(41.3)$ & $27(57.5)$ & \\
\hline Marital status (\%) & \multicolumn{2}{|c|}{} & \\
Not married & $6(10.0)$ & $1(1.8)$ & \\
Married & $41(68.3)$ & $13(23.2)$ & $<0.0001$ \\
Single & $13(21.7)$ & $42(75.0)$ & \\
\hline
\end{tabular}

$\mathrm{SD}=$ Standard deviation 
Table 2

Association between Risk Factors and IHDS Score Cut-off Scores for Treatment Naïve HIV Seropositive Subjects $(\mathrm{N}=60)$

\begin{tabular}{|l|c|c|c|}
\hline A. IHDS Performance for HIV Seropositive and Seronegative Participants \\
\hline IHDS Scores & $10.0(1.4)$ & $10.6(1.4)$ & 0.04 \\
Total & $3.4(0.7)$ & $3.5(0.6)$ & 0.12 \\
Memory-recall & $3.1(0.9)$ & $3.3(0.8)$ & 0.19 \\
Motor speed & $3.6(0.9)$ & $3.7(0.6)$ & 0.29 \\
Psychomotor speed & $3.6(0.8)$ & $3.8(0.6)$ & 0.32 \\
Antisaccade test &
\end{tabular}

\begin{tabular}{|c|c|c|}
\hline \multicolumn{3}{|c|}{ B. Risk Factors Associated with Impairment Using an IHDS Cut-off of 9.0 } \\
\hline Risk Factor & IHDS Cut-off Score $\leq 9.0$ & $P$ value $\boldsymbol{s} .0$ \\
\hline \multicolumn{3}{|l|}{ Age $(\%)$} \\
\hline Age $>38$ & $4 / 15(26.7)$ & 0.78 \\
\hline $34 \leq$ Age $\leq 38$ & $4 / 13(30.8)$ & \\
\hline $29 \leq$ Age $\leq 33$ & $3 / 19(15.8)$ & \\
\hline Age $<29$ & $3 / 13(23.1)$ & \\
\hline \multicolumn{3}{|l|}{ Gender $(\%)$} \\
\hline Female & $11 / 37(29.7)$ & 0.14 \\
\hline Male & $3 / 23(13.0)$ & \\
\hline \multicolumn{3}{|l|}{ Education $(\%)$} \\
\hline Primary & $6 / 12(50.0)$ & 0.15 \\
\hline Secondary & $3 / 15(20.0)$ & \\
\hline Tertiary & $4 / 19(21.1)$ & \\
\hline \multicolumn{3}{|l|}{ Marital Status (\%) } \\
\hline Not Currently Married & $2 / 6(33.3)$ & 0.59 \\
\hline Married & $8 / 41(19.5)$ & \\
\hline Single & $4 / 13(30.8)$ & \\
\hline \multicolumn{3}{|l|}{ CD4 Count (\%) } \\
\hline$<100$ & $7 / 12(58.3)$ & 0.01 \\
\hline $100-200$ & $1 / 11(9.1)$ & \\
\hline $201-350$ & 2/17 (11.8) & \\
\hline $350+$ & $3 / 17(17.7)$ & \\
\hline $\mathrm{CD} 4$ Count $(\mathrm{N}$, mean $\pm \mathrm{SD})$ & $13,178.9 \pm 206.8$ & 0.06 \\
\hline Log RNA ( \pm SD) & $12,5.0 \pm 0.8$ & 0.25 \\
\hline \multicolumn{3}{|l|}{ WHO Stage (\%) } \\
\hline 1 & $5 / 30(16.7)$ & 0.04 \\
\hline
\end{tabular}




\begin{tabular}{|l|c|c|}
\hline \multicolumn{2}{l}{ B. Risk Factors Associated with Impairment Using an IHDS Cut-off of 9.0 } \\
\hline Risk Factor & IHDS Cut-off Score $\leq \mathbf{9 . 0}$ & P value $\mathbf{9 . 0}$ \\
\hline 2 & $9 / 22(40.9)$ & \\
3 & $0 / 7(0.0)$ & \\
\hline Karnofsky Performance Scale (\%) & & \\
$\leq 50$ & $2 / 2(100)$ & \\
$>50$ & $12 / 58(20.7)$ & 0.05 \\
\hline
\end{tabular}


Table 3

Neuropsychological Test Results for HIV-1 Seropositive and Seronegative Subjects

\begin{tabular}{|l|c|c|c|c|}
\hline Neuropsychological Test & HIV- (N= 11) & HIV+ (N=15) & P Value & Effect Size \\
\hline Verbal Fluency & & & & \\
Action Fluency & $13.9(4.5)$ & $10.2(4.0)$ & 0.049 & 0.82 \\
Animal fluency & $12.5(2.8)$ & $11.7(3.0)$ & $\mathrm{ns}$ & 0.27 \\
Letter Fluency & $32.7(9.2)$ & $24.4(12.2)$ & 0.07 & 0.73 \\
\hline Processing Speed & & & & \\
Digit Symbol & $52.3(18.0)$ & $44.4(18.7)$ & $\mathrm{ns}$ & 0.42 \\
Symbol Search & $19.3(9.7)$ & $17.1(7.4)$ & $\mathrm{ns}$ & 0.25 \\
Trails A & $66.8(35.1)$ & $71.3(24.8)$ & $\mathrm{ns}$ & 0.15 \\
Color Trails 1 & $72.5(34.8)$ & $91.3(36.6)$ & $\mathrm{ns}$ & 0.51 \\
Stroop Word reading & $68.2(18.5)$ & $58.5(11.6)$ & $\mathrm{ns}$ & 0.63 \\
Stroop Color naming & $45.2(11.2)$ & $43.0(13.0)$ & $\mathrm{ns}$ & 0.17 \\
\hline Attention/Working Memory & & & & \\
PASAT-50 & $33.3(10.2)$ & $28.7(11.6)$ & $\mathrm{ns}$ & 0.40 \\
Spatial Span & $14.9(3.8)$ & $12.0(4.5)$ & 0.08 & 0.67 \\
\hline Abstraction/Executive & & & & \\
Color Trails 2 & $129.1(40.2)$ & $134.2(43.6)$ & $\mathrm{ns}$ & 0.12 \\
Stroop Color-Word & $29.8(10.0)$ & $29.8(7.3)$ & $\mathrm{ns}$ & 0.00 \\
\hline Learning & & & & \\
BVMT-R Learning & $21.7(7.3)$ & $19.5(9.7)$ & $\mathrm{ns}$ & 0.24 \\
HVLT-R Learning & $23.2(3.2)$ & $21.1(4.0)$ & $\mathrm{ns}$ & 0.55 \\
\hline Recall & & & & 0.52 \\
BVMT-R Delay & $7.7(2.2)$ & $7.5(3.7)$ & & 0.06 \\
HVLT-R Delay & $8.1(2.2)$ & $6.5(1.7)$ & 0.044 & 0.81 \\
\hline Motor & & & & \\
Pegs Dominant & & & & \\
\hline
\end{tabular}

